\title{
A Comparative Study between the Direct and Overheard Speech of Primary Caregiver of Late Talkers and Typically Developing Infants
}

\author{
Jiyeon Lee, Dongsun Yim \\ Department of Communication Disorders, Ewha Womans University, Seoul, Korea
}

Correspondence: Dongsun Yim, PhD Department of Communication Disorders, Ewha Womans University, 52 Ewhayeodae-gil, Seodamun-gu, Seoul 03760, Korea

Tel: $+82-2-3277-6720$

Fax: $+82-2-3277-2122$

E-mail: sunyim@ewha.ac.kr

Received: January 5, 2017

Revised: April 25, 2017

Accepted: May 12, 2017

\begin{abstract}
Objectives: Mother's language input is the most meaningful and impactful features for toddlers'language development. The more children experience successful communication between mothers and the child the greater the positive effects on a child's lingual development. This study examines the frequency of linguistic stimulation input, and the linguistic competencies of late-talking infants. Methods: Thirty-two pairs of mothers and children participated in this study: 16 pairs of late-talking (LT) infants (18-36 months) with their mothers and 16 pairs of typically developing (TD) infants of the same age with their mothers. The mothers had a smartphone attached to their armbands that recorded child-direct speech and speech overhead by their children during the course of a week in their daily lives. Results: The results showed that the group of TD children's mothers had significantly higher child-directed speech than the group of LT children's mothers. Among 6 different subtypes of child-directed speech, LT mothers group showed higher results in 'questioning', 'demanding' than the TD mothers group; the LT mothers group showed lower in 'responding,'explanation \& naming', and 'attempting.' Conclusion: The experiment provided an evidence that the direct linguistic interaction between mother and child is an important factor for children's language development, and identifies language types used by mothers interacting with their children.
\end{abstract}

Keywords: Late talker, Mother-infant interaction, Mother's speech, Directed speech, Overheard speech
영유아기는 언어, 인지, 신체, 정서 및 사회성 발달이 서로 밀접한 관계를 맺으며 급격하게 발달하는 동시에 모든 발달의 기초가 이루 어지는 시기이다(Bates \& Snyder, 1987; Billeaud, 2003). 따라서 영 유아기는 언어발달 과정을 거치는데 결정적인 시기에 해당하므로 유아에게 있어서 초기 환경인 가정은 매우 중요하다. 가정에서는 부모가 유아의 출생 직후부터 다양한 상호작용을 통해 언어적 자 극 및 언어습득 경험을 제공함으로써 유아는 입력된 언어를 처리하 고 조정하는 능력이 발달하게 된다. 이는 타인과의 관계 형성과 사 회적 상호작용 능력을 기르는데 중요하며, 특히 유아와 가장 많은 시간을 보내게 되는주양육자는 필수적 요인이 될 수 있다. Vygotsky 의 사회적 상호작용주의 관점에 의하면 어머니와 유아 간 공유된 활동 속에서 어머니는 유아의 대화 상대자로서 비계설정자 역할을
담당하게 되어(Bondrova \& Leong, 1996) 어머니와 유아 간 서로 상 호작용하며 이루어지는 의사소통 형태가 유아의 언어발달에 긍정 적인 효과를 창출한다고 했다. 비계설정(scaffolding)은 사회적 중 재(social mediation)를 의미하며, 과제에 대한 유아의 수행력에 따 라 도움을 조절해감으로써 문제를 해결할 수 있도록 하는 것을 뜻 한다. 따라서 어머니와 유아 사이에 이루어지는 '대화'는 유아의 발 달을 촉진하는 기본적인 요건이 되며, 이를 분석하는데 있어서 중 요한 이론적 틀을 제공하고 있다. 이처럼 유아에게 주어진 환경과 타인과 상호작용하며 발달하는 초기언어는 이후 지식의 습득, 직 업적 성취 등에 지대한 영향을 주기 때문에 언어의 어려움에 대한 관련 변인을 밝히는 것은 중요하다.

아동의 정상적 언어발달 과정을 살펴보면, 3 개월 이전의 영아는 
울음, 미소, 눈 맞춤 등으로 초보적인 의사소통 행동을 나타내고, 이후 자신의 소리내기, 제스처 그리고 상대자와 눈 맞추기 등이 성 인에게 영향을 미칠 수 있다는 것을 깨닫게 되어 점차 영아 스스로 계획된 목적을 이루기 위해서 팔을 벌리거나 우스꽝스러운 행동을 보이기도 한다. 생후 11-14개월경이 되면 의도적 의사소통 행동이 나타나게 되며 이러한 단계를 거치면서 점차 언어적 의사소통 단계 에 이르게 된다. 이는 성인, 특히 주양육자와 상호작용을 통해 언어, 신체, 인지발달이 서로 긴밀한 관계를 맺으며 발달하여 12 개월 전 후에 첫 낱말이 산출되며, 이후 습득하는 어휘 수가 점차 늘다가 18-24개월경이 되면 어휘의 습득 속도가 급격히 빨라지는 어휘 폭 발기(vocabulary burst)를 보인다(Bates et al., 1994). 3세경에는 습 득하는 어휘의 양이 보다 증가하고 계속해서 언어발달이 이루어지 며 이러한 발달은 평생에 걸쳐 지속된다(Lee \& Lee, 2007; Lee, Pyun $\&$ Kwak, 2011). 이는 모든 일반 아동에게서 동일하게 나타나는 것 은 아니지만 일반적인 언어발달 형태이다. 그런데 24-35개월 사이 에 표현어휘 수가 50 개 미만이거나, 36 개월 이전에 두 낱말 조합 산 출에 어려움을 보인다면 말 늦은 유아(late talker, LT)가 될 수 있다 (Hong \& Kim, 2005; Rescorla, 1989; Ukoumunne et al., 2012). 그 러나 초기 언어발달 속도가 늦었으나 4세경 또래와 비슷한 수준의 표현어휘수가 나타나면 늦게 말이 트인 아동(late bloomer) 혹은 정 상수준으로 회복한 아동(resolved late talkers, RLT)에 속하는 경 우가 있는 반면 4세 이후에도 계속해서 언어발달지연을 보이는 경 우 단순언어장애(specific language impairment, SLI)로 판정된다 (Bates, Dale, \& Thal, 1995; Fernald \& Marchman, 2012; Leonard, 1998; Ukoumunne et al., 2012). 이와 같이 발달선상에서 나타나는 언어적 차이에 대해 살펴보기 위해 말 늦은 유아를 예측할 수 있는 관련 변인을 밝히는 연구가 다양하게 이루어지고 있으며 본 연구에 서는 3 세 이전의 말 늦은 아동과 일반 아동 간의 주양육자의 언어 적 입력양에 대한 차이를 검토해보고자 한다.

유아의 언어능력은 유아가 가지고 태어난 내적요인과 유아를 둘 러싼 주위환경과 같은 외적요인들에 영향을 받는다. 이미 여러 학 자에 의해 주양육자의 언어사용 형태나 가정환경 및 대화가 유아 의 언어발달에 주요한 요인이 될 수 있다는 것을 밝혔으며, 주양육 자와 유아 간의 언어적 의사소통에 대해 강조하는 연구들이 다양 하다(Cazden, 1981; Zutell, 1980). 즉, 주양육자의 언어적 입력은 유 아의 언어발달에 미치는 주요한 요인이라 할 수 있으며(Hart \& Risley, 1995), 실제로 주양육자의 상호작용의 양과 질에 초점을 맞추 어 이루어진 연구가 다양하게 이루어졌다(Baumwell, Tamis-LeMonda, \& Bornstein, 1997; Chang, Lee, Kwak, \& Sung, 2003; Hart \& Risley, 1995; Huttenlocher, Haight, Bryk, Seltzer, \& Lyons, 1991;
Lee, Lee, \& Chang, 2004; Park \& Yim, 2015). 시간당 사용한 단어 의 수로 측정된 어머니의 입력량은 유아들의 어휘를 예측한다는 것을 발견하였으며, Huttenlocher 등(1991)의 연구에서는 약 2년 6 개월 동안 40 가족을 대상으로 부모-유아 간 상호작용을 분석한 결 과, 주양육자의 언어적 입력양이 어휘발달과 정적 상관관계가 있음 을 발견하였으며 질적으로는 언어적 반응성이 언어능력을 예측해 준다고 한 바 있다(Hart \& Risley, 1995). 또 다른 선행연구에서는 영아와 부모 간 상호작용을 살펴본 결과, 12 개월경 유아의 공동주 의(joint attention) 능력과 어휘력은 18 개월 유아와 주양육자의 상호 작용 및 언어발달과 관련이 있는 것으로 나타났다(Markus, Mundy, Morales, Delgado, \& Yale, 2000). 즉, 유아의 어휘력은 주양육자 와의 상호작용으로 인해 언어발달이 이루어진다고 볼 수 있으며 언 어의 어려움이 결정되기 전 유아에게 주양육자가 공동주의(joint attention)를 유도하거나 함께 주목해주는 경우가 높아야 하며 유 아의 발성 및 의도에 즉각적으로 언어 반응을 한 경우 유아의 언어 와 복잡한 감정적 발달에 긍정적인 영향을 줄 수 있다(Meins et al., 2003). 이러한 연구결과들을 바탕으로 실제 임상에서는 구조화된 자유놀이상황에서 자발화 평가를 통해 주양육자의 직접발화에서 나타나는 양상을 양적 및 질적으로 살펴보기도 한다(Lee \& Kim, 1999; Miller, 1991; Park \& Yim, 2015).

하지만 다수의 연구는 구조화된 자유놀이상황에서 유아와 주 양육자 간 상호작용을 분석하는 것에 초점을 두고 있으며, 주어진 시간 내에서 유아에게 제공되는 주양육자의 입력양과 질은 실제 일생생활에서 사용하는 주양육자의 언어적 형태를 대표하기에는 어려움이 따른다. 즉, 주양육자의 구체적인 발화형태를 이해하는데 부족함이 있다. 이러한 점을 고려하여 최근 이루어진 연구에서는 6 일간 주양육자와 유아 간 일상생활에서 나타난 발화에 대한 비율 을 살펴보았는데 그 결과, 19 개월 영아에게 직접적으로 발화한 비 율이 높을수록 24 개월이 된 영아의 표현어휘수가 더 높은 것으로 나타났다(Weisleder \& Fernald, 2013). 이는 유아와 주양육자 간 상 호작용이 오랫동안 지속적으로 이루어져야 하며 이를 통해 유아가 주양육자의 언어적 형태를 인식하고 모방하면서 언어능력이 보다 높아진 것이라고 생각할 수 있다. 한편 말 늦은 유아의 부모와 일반 유아 부모 간 언어적 입력양은 비슷하나 어떤 질적 측정요소에서 차이를 보고한 연구에서는 주양육자의 의사소통 특성에서 특히 유아의 말에 반응하기, 설명하기, 유아의 말을 모방 및 확장하기, 질 문하기 유형이 유아의 언어발달을 증진시키는 것으로 나타난 반면 (Chang \& Sung, 2011; Girolametto \& Weitzman, 2002; Vigil, Hodges, \& Klee, 2005), 말 늦은 유아 주양육자가 일반 유아 주양육자보 다 상호작용 시 모방과 확장을 적게 사용하는 것으로 보고된 바 있 
다(Vigil et al., 2005). 즉, 주양육자의 발화에 대한 양적 분석도 요구 되나 어떤 형태로 유아에게 언어적 자극을 제공하는지에 대한 질 적인 분석도 중요하다. 따라서 유아의 언어발달 예측요인을 살펴보 기 위해 주양육자의 일상적 언어형태를 양적 및 질적으로 분석할 필요가 있으며 이러한 분석은 구조화된 환경에서 벗어나 부모와 유아의 실제적 발화상황에 대한 양적 피드백을 제공함으로써 유 용한 임상적 의의를 제시할 수 있다.

한편 유아가 타인들 간의 대화를 통해간접적으로 언어를 습득할 수 있다고 보고한 선행연구 결과가 있다(Jones \& Adamson, 1987; Woollett, 1986). 예를 들어 형제 자매가 있는 가정에서 주양육자는 일반적으로 둘째 아이에 비해 먼저 태어난 아이와 더 긴밀한 언어 적 상호작용이 이루어지며 발화길이 및 언어적 복잡성 측면에서도 차이가 나타난다고 밝혔다. 즉, 나중에 태어난 아동은 맏이 아동에 비해 주양육자와의 상호작용보다 타인들의 대화에 보다 많이 노출 되었으며 이는 간접발화가 유아의 언어발달에 영향을 줄 수 있다고 해석할 수 있다. 하지만 일부 연구자들은 주양육자와 적은 상호작 용으로 인해 주양육자의 언어를 들을 기회가 줄어들고, 주양육자 의 언어를 모방하여 스스로 언어를 표현하는 기회가 줄어들면 이 후 언어학습에 큰 어려움이 나타날 수 있다고 주장하였다(Snow, 1972, 1977; Wellen, 1985). 이러한 선행연구를 통해 주양육자가 유 아에게 직접적인 상호작용을 통해 제공하는 직접발화의 양과 주양 육자와 타인과의 대화를 통해 간접적으로 자극을 받게 되는 간접 발화의 양을 비교해볼 필요가 있다.

또한 선행연구에서는 풍부한 언어적 입력을 제공받은 유아가 효 율적인 언어 수행력이 나타났다고 보고하였다(Hurtado, Marchman, \& Fernald, 2008; Park \& Yim, 2015; Yim, Park, Cheon, Lee, \& Lee, 2015). 이러한 가정환경 요인이 초기 문자언어 출현에도 긍 정적인 영향을 미치고, 가정에서 일찍부터 책을 활용하여 유아와 상호작용하고 다양한 언어자극 활동을 접했던 경험을 가지고 있는 아동의 경우, 학령기 때 읽고 쓰는 문해 활동에 핵심적인 역할을 한 다고 밝히고 있다(Durkin, 1961; Feitelson, Kita, \& Goldstein, 1986; Fitzgerald, 1993; Morrow, 1983; Yang, Yim, \& Bae, 2015). 따라서 언어발달은 주양육자 부모의 태도, 사회문화적인 배경 하에서 다 르게 나타나며 부모-유아 간의 상호작용에도 질적인 차이를 가져 온다는 견해를 바탕으로(Heath, 1983; Ninio, 1980; Wells, 1986) 유 아와 직접적인 언어적 상호작용에 대한 변인을 확인해볼 필요성이 제기되며 또한 어떤 언어적 형태가 영아의 언어능력을 예측해줄 수 있으며, 부정적으로 미치는 요인은 무엇인지 살펴볼 필요가 있다.

따라서 이러한 선행연구를 바탕으로 본 연구에서는 주양육자의 유아에 대한 직접적인 발화와 간접 발화의 빈도수는 어떻게 나타
나며, 이러한 주양육자의 직접적 의사소통 발화 하위유형에 대한 양상을 살펴보고자 한다. 동시에 본 연구는 주양육자-유아 간의 언 어적 상호작용을 위한 후속 연구에 대한 기반을 제공하는 것을 목 적으로 한다.

이에 따른 연구 질문은 다음과 같다. 첫째, 말 늦은 유아와 일반 유아의 주양육자 발화 유형(직접발화, 간접발화)에 따라 유의한 차 이가 있는가? 둘째, 말 늦은 유아와 일반 유아의 주양육자 직접발화 하위유형에서 유의한 차이가 있는가?

\section{연구방법}

\section{연구대상}

본 연구는 서울, 경기, 강원, 경남 지역에 거주하는 생활연령 18-36 개월의 말 늦은 유아와 주양육자 16쌍(18-36개월, 남 11, 여 5), 그리 고 이들과 생활연령을 일치시킨 일반 유아와 주양육자 16쌍(21-36 개월, 남 10, 여 6), 총 32 명을 대상으로 하였다.

말 늦은 유아(late talker)는 인지, 감각, 신경학적 결함 없이 표현 어휘 및 표현언어능력이 지체된 3세 이전의 영유아라고 정의한 Rescorla (1989)의 기준을 바탕으로 다음과 같은 조건에 따라 말 늦은 유아 집단의 대상자로 선정하였다. (1) 주양육자에 의해 언어발달 이 느리다고 보고된 유아 중에서, (2) 영아선별 교육진단검사(Developmental assessment for the Early Intervention Program planning, DEP; Jang, Seo, \& Ha, 2011)에서 인지검사 지능지수가 85점 (-1 SD) 이상이며, (3) 영·유아 언어발달 검사(Sequenced Language Scale for Infants, SELSI; Kim, Kim, Yoon, \& Kim, 2003)를 실시한 결과, 통합언어능력 또는 표현언어연령이 자신의 생활연령보다 6개 월 이상 지체되거나 - 1.25 표준편차 미만에 속하고(Kim, 2002; Kim et al., 2003; Thai \& Tobias, 1994; Weismer, Murray-Branch, \& Miller, 1994), (4) 한국판 맥아더-베이츠 의사소통발달 평가(Korean MacArthur-Bates Communicative Development Inventories, K M-B CDI; Pae \& Kwak, 2011) 결과, 표현어휘수가 $10 \%$ ile 미만에 속하며, (5) 기타 정서 및 심리문제, 시각, 청각 등 신체의 장애를 동반하고 있 지 않으며 다른 특이한 진단명이 보고되지 않은 유아로 선정하였다.

일반 유아는 (1) 주양육자에 의해 언어, 인지, 신체, 심리 및 행동 발달에 문제가 없다고 보고된 유아들 중에서, (2) 영아선별 교육진 단검사(DEP; Jang et al., 2010)에서 인지검사 지능지수가 85점(-1 $\mathrm{SD}$ ) 이상이며, (3) 영·유아 언어발달 검사(SELSI; Kim et al., 2003) 결과, 평균 이상(-1.25 SD 이상)의 언어발달에 속하고, (4) 한국판 맥 아더-베이츠 의사소통발달 평가(K M-B CDI; Pae \& Kwak, 2011) 결과, 표현어휘수가 정상발달범주(10\%ile 이상)에 속하며, (5) 기타 
정서 및 심리문제, 시각, 청각 등 신체의 장애를 동반하고 있지 않으 며 다른 특이한 진단명이 보고되지 않은 유아로 선정하였다.

말 늦은 유아의 주양육자 연령분포는 30대 13명, 40 대 3 명이며, 학력은 전문대 졸업 3 명, 대학교 졸업 10 명, 대학원 졸업 3 명으로 구 성되었다. 일반 유아의 주양육자 연령분포는 30 대 16 명이며, 전문 대 졸업 1 명, 대학교 졸업 12 명, 대학원 졸업 3 명으로 구성되었다. 연 구에 참여한 유아 및 부모는 온라인 카페 커뮤니티 등을 통하여 모 집되었으며, 모든 연구대상자는 부모의 동의를 구한 경우에 한해 연구대상자로 선정되었다.

위의 절차를 통해 선정된 일반 유아와 말 늦은 유아의 생활연령 과 형제자매 수에 대한 통제가 잘 이루어졌는지 살펴보기 위하여 $t$ test를 실시하였다. 그 결과, 일반 유아 집단과 말 늦은 유아 집단의 연령에서 유의한 차이가 나타나지 않았으며, 집단 간 형제자매 수 에서도 유의한 차이가 나타나지 않았다. 또한 일반 유아 주양육자 와 말 늦은 유아의 주양육자의 생활연령과 교육년수에 대한 통제 가 잘 이루어졌는지 살펴보기 위해 $t$-검정을 실시한 결과, 집단 간 생활연령과 교육년수에서 유의한 차이가 나타나지 않았다.

본 연구에 참여한 유아와주양육자 기본정보는 Table 1과 같다.

\section{연구과제}

\section{주양육자 직접발화 및 간접발화 검사}

주양육자의 직접발화 및 간접발화 검사는 유아의 주양육자에게 하루 평균 5시간씩(범위: 4-7시간) 일주일 동안 자연스러운 가정생 활에서 나타난 주양육자 발화를 스마트폰 '고급음성레코드' 어플 리케이션에 녹음하도록 하였으며, 동일한 시간대에 일주일 내내 가

Table 1. Participants' characteristics

\begin{tabular}{lccc}
\hline \multicolumn{1}{c}{ LT group } & TD group & $p$-value \\
\hline $\begin{array}{l}\text { Toddlers } \\
\text { CA (mo) }\end{array}$ & $29.06(4.86)$ & $28.25(6.00)$ & .677 \\
DEP & & & \\
Cognition & $104.38(9.89)$ & $110.19(7.77)$ & .075 \\
SELSI & & & \\
ELA (mo) & $37.44(13.20)$ & $50.44(5.97)$ & $.001^{* *}$ \\
CLA (mo) & $85.19(21.07)$ & $101.94(11.36)$ & $.009^{* *}$ \\
K M-B CDI & $138.00(134.40)$ & $420.38(203.60)$ & $.000^{* *}$ \\
Sibling(no) & $.75(.58)$ & $.81(.54)$ & .775 \\
Mothers & & & \\
CA (yr) & $35.50(5.23)$ & $34.25(1.70)$ & .37 \\
Period of education (yr) & $16.00(1.26)$ & $16.25(1.0)$ & .54 \\
\hline
\end{tabular}

Values are presented as mean (SD).

$\mathrm{LT}=$ late talker; $\mathrm{TD}=$ typical development; $\mathrm{CA}=$ chronological age; $\mathrm{ELA}=$ expressive language age; $\mathrm{CLA}=$ combined language age.

${ }^{*} p<.05,{ }^{* *} p<.01$.
정에만 있는 상황이 되지 못할 경우를 대비하여 일주일 연속으로 녹음하지 않더라도 간헐적으로 녹음을 할 수 있으나 7일간 총 35 시 간의 녹음시간을 채우도록 요구하였다. 녹음상황은 유아가 깨어있 을 때 실시해야 하며 유아 및 주양육자 외 타인이 있더라도 이를 의 식하지 않고 자연스러운 상황을 녹음 하도록 하였다. 하지만 주양 육자의 판단에 따라 녹음되지 않아야 할 상황인 경우 일시정지 버 튼을 누르고 개별적 상황이 끝난 경우 다시 녹음 버튼을 눌러 연속 해서 녹음을 실시하였다. 녹음방법은 녹음이라는 제한된 상황을 고려하여 보다 정확한 분석을 위해 주양육자가 스마트폰 암밴드를 직접 착용하여 스마트폰 내장 $\mathrm{MIC}$ 를 통해 실시하였다. 본 연구에서 주양육자의 직접발화와 간접발화 분석 기준은 Weisleder와 Fernald (2013) 연구를 참고하여 (1) 유아와 자연스러운 상호작용을 시 작할 때, (2) 주양육자가 유아에게 언어적 형태를 갖춘 단어 및 문장 으로 직접적인 언어자극을 제공한 경우, 모두 직접발화(child-direct speech)로 간주하여 분석하였다. 한편 검사자의 기준에서 (1) 주양육자가 유아와 같은 공간에 있다고 판단될 때, 즉, 유아가 주양 육자의 발화를 들을 수 있는 경우, (2) 주양육자가 유아가 아닌 타인 에게 언어자극을 제공한 경우, 즉, 유아가 타인에게 제공하는 언어를 엿들을 수 있는 경우, 모두 간접발화(overheard speech)로 간주하여 분석하였다. 검사자는 녹음된 모든 발화에 대해서 소리를 듣고 유 아가 주양육자와 가까이 있다고 판단되는 경우에만 발화를 분석하 였고, 검사자의 기준에서 알아듣기 어려운 말소리와 발화상대자가 불분명하다고 판단되면 분석에서 제외하였으며 해당되는 발화 유 형에 각각 1 점을 부과하였다.

\section{주양육자의 직접발화 하위유형}

주양육자의 직접발화 하위유형은 위에 제시된 주양육자의 직접 발화 및 간접발화 검사에서 녹음된 발화를 분석하여 살펴보았다. 즉, 하루 평균 5 시간씩 일주일 동안 자연스러운 가정생활에서 나타 난주양육자 발화를 스마트폰 녹음 어플리케이션을 통하여 실시한 다. 하지만 유아의 입장에서 주양육자가 유아가 아닌 타인에게 언 어적 자극을 제공한 주양육자의 간접발화는 제외하였으며, 직접발 화 빈도수가 가장 많이 산출된 1 일이 일주일동안 녹음상황에서 주 양육자가 산출한 전체발화 빈도수와 높은 상관이 나타난 Weisleder와 Fernald (2013)의 연구결과에 근거하여 본 연구에서는 일주일 동안 녹음된 주양육자 발화 중에 유아에게 직접적으로 언어자극 을 제공한 입력양이 가장 많은 날 하루를 선정하여 직접발화 유형 을 분석하였다. 유아에 대한 주양육자의 직접적인 언어적 입력 유 형은 Kim과 Kwak (2010), $\mathrm{Ha}$ (2011) 연구를 참고하여 수정 및 보완 하였다. Kim과 Kwak (2010) 연구에서는 Bornstein과 Tamis-LeM- 
onda $(1989,1990)$ 의 연구에서 사용한 방법을 기초로 한 Shin, Kwak 과 Bornstein (2007)의 코딩체계에 근거하여 유아에 대한 주양육자 의 언어적 반응성 유형을 승인(affirmation), 모방(imitation), 묘사 (describing), 질문(question), 놀이촉진/시범(play prompt), 탐색 촉 진(exploratory prompt)으로 분류하여 살펴보았다. 이는 유아가 상 호작용하고자 하는 것을 언어적 혹은 제스처로 표현하였을 때 주 양육자가 긍정적이고 의미 있는 언어적 행동을 보이는지 여부로 정 의되었다. 한편 $\mathrm{Ha}$ (2011) 연구에서는 주양육자 발화를 설명하기, 질문하기, 반응하기, 지시·제안하기, 부르기, 주의환기, 대답하기, 금 지하기로 크게 8항목으로 분류한 뒤 세부항목으로 다시 분류하였 다. 설명하기의 경우 주양육자가 유아의 상호작용 의도나 관심보다 사물이나 상황에 대해 설명을 주로 해주는 반면, 반응하기의 경우 는 유아의 상호작용 의도가 있는 구어 및 제스처에 대한 주양육자 의 모든 반응을 포함하였다. 이와 같이 유아와 주양육자 간 상호작 용에서 나타나는 주양육자의 언어적 입력 유형을 분석한 연구들을 토대로 본 연구에서는 크게 질문하기, 혼잣말하기, 시도하기, 반응 하기, 설명 및 명명하기, 요구하기 6항목으로 분류한 뒤 다시 세부 항목을 분류하였다. 먼저 질문하기 유형에서는 예/아니오 질문, 정 보추구 질문, 개방형 질문, 되묻기로 세분화하였으며 시도하기 유형 에서는 상호작용시도, 주의환기로 분류하고, 유아의 제스처 및 언 어에 대한 반응하기 유형에서는 단순반응, 확장/확대, 평행적 발화, 모방 및 반복으로 분류하였으며, 요구하기 유형에서는 행동요구, 사물요구, 말요구로 세분화하였다. 이에 대한 정의는 다음과 같다.

(1) 질문하기는 유아에게 명확한 대답을 유도하는 형태(예/아니 오 질문, 정보추구 질문, 되묻기)와 특정한 반응이 요구되지 않는 질문(개방형 질문)으로 정의한다. 예시) 엄마랑 블록놀 이 할까? 이거 뭐야? 기린이 우리 보고 웃고 있네 ? 뭐라구?

(2) 반응하기는 유아가 몸짓 및 언어로 표현했을 때 어머니가 언어 적으로 반응해준 경우로 긍정 또는 부정적으로 단순히 반응 한 경우, 유아의 행동 또는 언어를 의미 및 문법적으로 확장/확 대시킨 경우, 유아의 입장에서 표현해주는 평행적 발화 형태, 유아의 언어를 모방하거나 반복으로 반응한 형태로 정의한다. 예시) 잘 했어, 유아가 “어아”라고 했을 때, "엄마랑 하자고 " 라고 반응, 유아가 “아”라고 했을 때 그대로 "아”라고 반응

(3) 혼잣말하기는 어머니가 누군가를 흥내 내거나 유아에게 간 접적으로 언어적 모델링을 제공하여 말을 전달하는 표현인 경우로 정의한다. 예시) 전화놀이 상황에서 유아를 보면서 주 양육자가 “내가 전화 받아야지 ?”라고 표현

(4) 시도하기는 유아와 행동 및 언어적 상호작용을 시도하기 위 한 언어적 형태나 유아의 관심을 끌기 위한 표현인 경우로 정
의한다. 예시) 우리 같이 놀자.

(5) 설명 및 명명하기는 사물에 대한 설명 및 명명을 하거나 경험에 대한 이야기를 하는 경우로 정의한다. 예시) 이거는 $\mathrm{OO}$ 라고 해. (6) 요구하기는 유아에게 행동이나 사물 또는 말을 요구하는 경 우로 정의한다. 예시) 이거 주세요. OO라고 말해봐.

어머니의 언어적 입력 유형은 유아의 행동, 발성 및 구어를 유도 하거나 이에 반응하는 언어적 형태를 모두 포함하여 분석하였으나, 알아듣기 어려운 말이나 언어적 형태가 아닌 경우 분석에서 제외시 켰으며 앞서 제시한 6가지 어머니의 언어적 입력유형을 제외한 또 다른 언어적 유형은 분석에서 배제되었다.

\section{자료수집}

본 연구의 대상자는 주로 온라인 카페 커뮤니티를 통해 참여하 였으므로 방문 전 미리 유아에 대한 인지능력 및 언어능력검사가 제공되고 유아와 주양육자 간 상호작용에서 나타나는 주양육자의 발화에 대한 분석을 실시하기 위해 가정 내 일상적인 상황을 녹음 해야 한다는 본 연구의 절차 내용을 설명한 뒤 이에 동의한 대상자 들에 한해 검사자가 직접 가정에 방문하여 본 연구에 대한 동의서 와 연구 자료를 수집하였다.

유아의 인지 및 언어능력검사가 끝난 후 검사자는 주양육자의 일 상적 발화 빈도수 및 발화 유형을 살펴보기 위해 녹음해야 할 스마 트폰과 녹음 시 팔에 착용해야 하는 스마트폰 암밴드를 제공하고, 스마트폰 녹음 어플리케이션 사용방법에 대해 자세히 설명하였다. 또한 녹음 시 유의할 점은 본 연구는 일상적으로 나타나는 주양육 자 발화 형태를 살펴보는 것으로 평소 생활하는 그대로 자연스러 운 상황을 녹음하도록 요구하였으며 평소보다 유아와 더 많이 상 호작용 하는 것과 같은 인위적인 행동을 삼가도록 상기시키고, 보 다 정확한 녹음을 위해 스마트폰 암밴드를 착용하고 생활하도록 요구하였다. 본 연구가 실시된 이후 검사자는 녹음상황과 스마트폰 고장 등의 문제를 매번 확인하였으며, 녹음이 모두 끝난 경우 다시 가정에 방문하여 녹음된 시간을 확인하고 유아의 인지 및 언어검 사 결과에 대한 보고서를 제공하여 검사 결과에 대해 이해하기 쉽 도록 안내하였으며 평소 유아와 상호작용 시 주의해야 할 의사소 통 방법에 대해 간단하게 안내하고 본 연구의 수집절차를 마쳤다.

\section{자료분석}

유아에 대한 주양육자의 직접발화와 간접발화에 대한 빈도수 분 석은 일주일 동안 총 녹음된 시간 중 35 시간으로 통일하여 녹음상 황에서 나타난 모든 발화 빈도수를 측정하였으며, 유아에게 직접 적인 언어자극을 제공한 경우 직접발화에 1 점, 유아 외 타인에게 언 
어자극을 제공한 경우 간접발화에 1점을 기록하였다. 주양육자 발 화의 구분은 $\operatorname{Kim}$ (2002)의 ‘자발화 표본수집 및 기록'의 내용을 기 준으로 하였으며, 35시간 동안 나타난 주양육자의 직접발화 빈도수 와 간접발화 빈도수를 각각 산출하고 직접발화와 간접발화 빈도수 를 모두 합한 전체발화 빈도수를 산출했다.

다음으로 일주일 동안 측정된 직접발화 빈도수 중에 가장 빈도 수가 높게 나타난 하루를 선정하여 유아의 입장에 따라 나타난 주 양육자의 간접발화를 제외하고 유아에 대한 주양육자의 직접적인 언어자극 형태만을 따로 분석하였다. 하지만 직접발화 빈도수가 가 장 많이 산출된 하루를 선정한 결과, 주양육자마다 녹음된 시간의 양적 차이가 크게 나타났으며 주양육자가 하루에 산출한 최소 직 접발화 총 빈도수가 500 발화로 나타나, 본 연구대상 주양육자 모두 녹음시작부터 나타난 발화를 기점으로 500 발화까지로 통일하여 각 하위유형을 분석하였다. 직접발화 유형은 질문하기(예/아니오 질문, 정보추구 질문, 개방형 질문, 되묻기), 혼잣말하기, 시도하기 (상호작용 시도, 주의환기), 반응(단순반응, 확장/확대, 평행적 발 화, 모방/반복), 설명 및 명명하기, 요구하기(행동요구, 사물요구, 말 요구)에 따라 해당되는 유형에 1점을 기록하였다.

\section{신뢰도}

주양육자의 직접발화 및 간접발화 분석 신뢰도를 검정하기 위해 검사자 간 일치도를 산출하였다. 언어병리학과 석사과정 재학 중에 있으며 2 급 언어치료사자격증을 소지하고 있는 1 명이 연구자와 함 께 분석을 실시하였고, 분석에 앞서 연구자는 제 2 평가자에게 분석 방법과 기준에 대하여 설명하였다. 신뢰도는 연구대상자 전체 수집 된 발화 자료의 약 $20 \%$ 를 임의로 추출하여 유아의 입장에 따른 주 양육자의 직접발화와 간접발화에 대해 본 연구의 분석기준에 따라 각각 독립적으로 분석하였다. 연구자와 평가자 간의 일치한 반응 을 전체 반응수로 나눈 다음 100 을 곱하여 신뢰도를 산출하여 비 교하였으며, 그 결과 주양육자의 직접발화 및 간접발화에 대한 연 구자와 검사자 간 분석결과 신뢰도는 $94.87 \%$ 였다.

주양육자의 유아에 대한 직접발화 유형 분석 신뢰도를 검정하기 위해 검사자 간 일치도를 산출하였다. 모든 주양육자의 발화에 대 한 분석이 끝나고 일주일 이후에 전체 수집된 자료의 약 $16 \%$ 를 임 의로 추출하여 주양육자가 유아에게 직접적으로 제공한 언어자극 유형에 대해 본 연구의 분석기준에 따라 재분석을 실시하였다. 검 사자 간의 일치한 반응을 전체 반응수로 나누고 100 을 곱하여 신 뢰도를 산출하여 비교한 결과, 주양육자의 직접발화 유형에 대한 검사자 내 분석결과 신뢰도는 $97.62 \%$ 였다.

\section{자료의 통계적 처리}

말 늦은 유아와 일반 유아의 주양육자 발화 유형(직접발화, 간접 발화)에서 유의미한 차이가 나타나는지 알아보기 위해 이원혼합 분산분석(two-way mixed ANOVA)을 실시하였으며, 말 늦은 유아 와 일반 유아 주양육자의 6가지 직접발화 하위유형에서 유의한 차 이가 나타나는지 검토하기 위해 일원분산분석(one-way ANOVA) 을 실시하였다. 모든 통계적 분석은 IBM Statistics version 23 (IBM SPSS, Armonk, NY, USA)을 사용하였다.

\section{연구결과}

\section{집단 간(말 늦은 유아, 일반 유아) 주양육자 발화 유형 (직접발화, 간접발화) 차이}

말 늦은 유아 집단과 일반 유아 집단에 따른 주양육자 직접발화, 간접발화에 대한 기술통계는 Table 2와 같다.

말 늦은 유아 집단에서 나타난 직접발화 빈도수는 일반 유아 집 단에서 나타난 직접발화 빈도수 보다 낮게 나타났으며, 집단에 따 른 간접발화 빈도수는 말 늦은 유아 집단에서 일반 유아 집단보다 높게 나타났다.

직접발화 빈도수 및 간접발화 빈도수에 대한 기술통계 결과가 통 계적으로 유의한지 살펴보고, 집단에 따른 직접발화 및 간접발화 에 대한 두 가지 변인 간의 상호작용 효과를 검증하기 위해 이원혼 합분산분석(two-way mixed ANOVA)을 실시하였다.

그 결과, 집단에 대한 주효과가 통계적으로 유의하였다 $\left(F_{(1,30)}=\right.$ $215.13, p<.0001)$. 즉, 말 늦은 유아 $(2,738.03)$ 집단의 경우 일반 유아 (2,574.88)에 비해 더 높게 나타났다. 집단 내 요인으로 발화 유형에 관한 주효과가 통계적으로 유의하였다 $\left(F_{(1,30)}=13.55, p \leq .001\right)$. 즉, 직접발화 $(3,223.94)$ 가 간접발화(2,088.97)에 비해 통계적으로 유의 하게 더 높게 나타났다.

이에 대한 집단 및 발화에 관한 상호작용이 통계적으로 유의하 였다 $\left(F_{(1,30)}=11.64, p<.005\right)$. 즉, 발화 빈도수에 따른 점수 차이가 말 늦은 유아 집단에서보다 일반 유아 집단에서 통계적으로 유의 하게 큰 것으로 나타났다. 다시 말해 말 늦은 유아 집단보다 일반 유 아 집단의 직접발화 빈도수가 유의하게 높은 것으로 나타났다. 두

Table 2. Descriptive statistics of the mother's speech by two groups

\begin{tabular}{lll}
\hline & \multicolumn{1}{c}{ Direct speech } & Overheard speech \\
\hline $\operatorname{LT}$ group $(\mathrm{N}=16)$ & $2,779.69(1,359.44)$ & $2,696.38(1,568.86)$ \\
TD group $(\mathrm{N}=16)$ & $3,668.19(1,509.63)$ & $1,481.56(807.37)$ \\
\hline
\end{tabular}

Values are presented as mean (SD).

$\mathrm{LT}=$ late talker; $\mathrm{TD}$ = typically developing toddlers. 


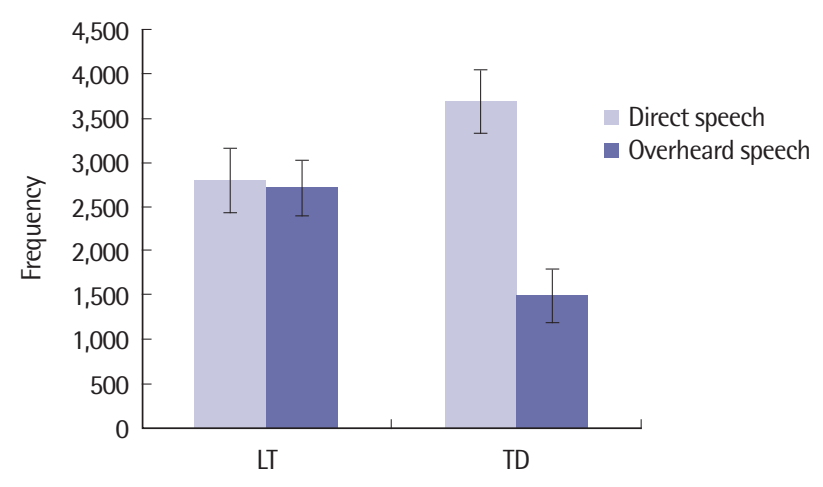

Figure 1. The frequency of direct speech and overheard speech by two groups. $\mathrm{LT}=$ late talker; $\mathrm{TD}=$ typically developing toddlers.

Table 3. Descriptive subtypes of the mother's direct speech

\begin{tabular}{lcc}
\hline Subtype & LT group $(\mathrm{N}=16)$ & TD group $(\mathrm{N}=16)$ \\
\hline Responding & $136.94(40.96)$ & $188.13(38.69)$ \\
Questioning & $183.31(32.67)$ & $145.00(24.34)$ \\
Explanation \& naming & $29.63(15.43)$ & $56.13(26.35)$ \\
Demanding & $112.75(53.38)$ & $55.13(22.98)$ \\
Attempting & $21.56(18.67)$ & $36.81(17.29)$ \\
Monologue & $15.81(20.99)$ & $18.81(22.15)$ \\
\hline
\end{tabular}

Values are presented as mean (SD).

$\mathrm{LT}=$ late talker; $\mathrm{TD}=$ typically developing toddlers .

집단 간 직접발화와 간접발화에 따른 차이를 비교한 그래프를 Figure 1 에 제시하였다.

\section{집단 간(말 늦은 유아, 일반 유아) 주양육자 직접발화 하위유형 차이}

말 늦은 유아 집단과 일반 유아 집단에 따른 주양육자의 직접발 화하위유형에 대한 기술통계는 Table 3과 같다.

일반 유아 집단에서 산출한 발화 유형 빈도수를 살펴보면 반응 하기>질문하기 > 설명 및 명명하기>요구하기 >시도하기 > 혼잣말 하기 순으로 나타나 ‘반응하기' 유형이 가장 높은 비율로 나타난 반 면, 말 늦은 유아 집단에서 산출한 발화 유형에 따른 빈도수는 질문 하기 > 반응하기 > 요구하기 > 설명 및 명명하기 >시도하기>혼잣말 하기 순으로 나타나 ‘질문하기' 유형이 가장 높은 비율로 나타났다.

말 늦은 유아 주양육자와 일반 유아 주양육자의 6가지 직접발화 하위유형에 대해 위와 같은 기술통계 결과가 통계적으로 유의한지 알아보기 위해 일원분산분석(one-way ANOVA)을 실시하였다.

그 결과, 6 가지 직접발화 하위유형 중 '반응하기' $\left(F_{(1,30)}=13.21\right.$, $p \leq .001)$, '질문하기' $\left(F_{(1,30)}=14.15, p \leq .001\right)$ 와 '설명 및 명명하기' $\left(F_{(1,30)}=12.05, p<.005\right)$, '요구하기' $\left(F_{(1,30)}=15.73, p<.0001\right)$, '시도하

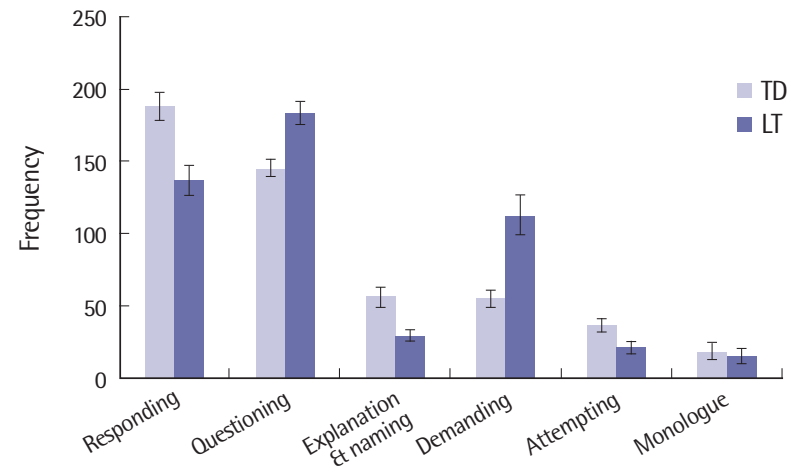

Figure 2. The 6 subtypes of mother's direct speech by two groups. $\mathrm{LT}=$ late talker; $\mathrm{TD}=$ typically developing toddlers.

기' $\left(F_{(1,30)}=5.75, p<.05\right)$ 유형에서 집단 간 차이가 통계적으로 유의 하였다. 하지만 두 집단에 대한 '혼잣말하기' 유형에서는 통계적으 로 유의한 차이가 나타나지 않았다 $\left(F_{(1,30)}=.16, p>.05\right)$. 즉, 말 늦은 유아 주양육자가 일반 유아 주양육자 보다 질문하기, 요구하기 유 형에서 발화 빈도수가 유의하게 높게 나타난 반면, 반응하기, 설명 및 명명하기, 시도하기 유형에서는 통계적으로 유의하게 낮게 나타 났다. 집단에 따른 주양육자의 6가지 직접발화 하위유형 빈도수에 대한 그래프를 Figure 2에 제시하였다.

\section{논의 및 결론}

본 연구에서는 말 늦은 유아의 초기 언어 결함을 예측하는 요인 을 살펴보기 위해 18-36개월에 속한 유아를 대상으로 (1) 말 늦은 유아 집단과 또래 일반 유아 집단에 따른 주양육자의 직접적인 발 화와 간접발화 빈도수가 어떻게 나타나며, (2) 이에 따라 두 집단 주 양육자의 직접적 의사소통 발화 패턴 양상을 살펴보고자 하였다.

\section{말 늦은 유아 및 일반 유아 주양육자의 직접발화와 간접발화 비교}

18-36개월에 속한 말 늦은 유아 집단과 일반 유아 집단간 주양육 자의 직접발화와 간접발화 빈도수에 대한 차이가 있는지 알아보기 위하여 가정 내 일상생활 상황을 녹음하여 연구실험을 진행하였다.

본 연구에서는 각 집단의 주양육자가 산출한 직접발화 총 빈도 수와 간접발화 총 빈도수로 차이가 나타났는지 살펴본 결과, 일반 유아 주양육자 집단에서 말 늦은 유아 주양육자 집단 보다 직접발 화 빈도수가 유의하게 높게 산출하였다. 즉, 말 늦은 유아의 주양육 자는 유아와 직접적으로 상호작용하는 시간이 일반 유아 주양육 자보다 유의하게 적을 뿐만 아니라 유아에게 제공하는 언어적 입력 
양이 유의하게 낮은 것을 의미한다. 이러한 결과는 유아와 주양육 자의 상호작용과 유아의 언어발달이 서로 밀접한 관련이 있는 것으 로 나타난 선행연구를 뒷받침 하였으며(Markus et al., 2000), 유아 에게 직접적으로 발화한 비율이 높을수록 이후 유아의 표현어휘수 가 상대적으로 높게 나타났다고 밝힌 선행연구 결과를 뒷받침하였 다(Weisleder \& Fernald, 2013). 또한 어휘집을 짓기 시작할 때 주양 육자로부터 다양한 언어적 모델링을 제공해주는 것에 따라 유아의 어휘가 빨리 성장할 수 있다고 주장한 선행연구결과를 지지한다 (Hart \& Risley, 1995; Hoff, 2003; Rowe \& Goldin-Meadow, 2009). 유아의 언어능력은 부모로부터 이야기가 더 많이 제공됨에 따라 언어를 해석할 기회가 보다 많이 주어지고, 언어를 분절하거나 어 휘표상에 접근하면서 단어학습이 이루어지며 이러한 기술들은 연 습을 통해 익히고, 확장되어 나간다(Gershkoff-Stowe, 2002). 본 연 구에서도 직접적으로 언어적 상호작용이 오랫동안 지속된 유아가 보다 높은 언어능력을 보인 것으로 나타나 선행연구결과와 같은 맥 락이라 할 수 있다. 즉, 유아와 주양육자가 오랫동안 지속적으로 상 호작용할 경우, 유아는 일상생활에서 일상적 단어 및 언어에 노출 되고, 제공된 주양육자의 언어적 자극을 인식하고 모방하면서 친 숙한 단어들 먼저 빠르고 정확하게 습득하고, 점차 새로운 단어를 학습할 수 있게 되면서 어휘 및 언어발달이 빠르게 이루어진 것으 로 해석할 수 있다.

또한 유아는 주위 환경에서 제공된 언어적 모델링 및 행동을 모 방하고, 성인의 강화에 의해서 언어를 습득한다고 보았을 때, 주양 육자의 언어적 입력양이 언어발달과 밀접한 관련이 있는 것으로 유 추해볼 수 있다. 하지만 말 늦은 유아의 언어능력이 일반 유아에 비 해 현저히 제한되어 있기 때문에 주양육자의 직접적인 언어자극 빈 도가 상대적으로 적을 수 있다는 점을 고려하여 단순히 주양육자 의 발화만 말 늦은 아동의 제한된 언어능력의 원인이라고 볼 수 없 으므로 다각적인 방면에서 살펴볼 필요가 있다.

부가적으로 풍부한 대화를 하는 환경 속에서 자라난 유아는 이 후 이야기기술 습득과 일상적 내러티브 발달과도 유의한 상관이 있 다고 미루어 볼 때(Peterson, 1992; Reese, Haden, \& Fivush, 1993), 본 연구에 참여한 유아는 18-36개월에 속한 유아이므로 유아에게 직접적으로 상호작용한 주양육자의 대화 능력 및 대화방식이 3세 이후 이야기 및 문법발달에 있어서도 상당한 영향을 줄 수 있는지 후속연구에서 검토해 볼만 한 결과이다.

따라서 본 연구는 유아의 입장에서 일상 가정 내 생활에서 나타 나는 주양육자의 발화상대자에 따른 발화 유형을 구분해본 것으 로 일반 유아 주양육자가 제 3 의 발화상대자보다 본 연구대상자인 유아와 더 오랫동안 상호작용을 유지한 반면, 말 늦은 주양육자는
유아와 제 3 의 발화대상자들과 비슷한 수준으로 상호작용한 것으 로 유아와 오랫동안 지속적으로 상호작용을 해야 할 필요성이 보인 다. 즉, 유아의 언어발달 과정에서 주양육자가 타인보다 유아와 일 상생활 내에서 얼마나 오랫동안 상호작용하는지를 임상에서 확인 해야 할 필요성이 제기된다.

\section{말 늦은 유아 및 일반 유아 주양육자의 직접발화 하위유형 비교}

18-36개월에 속한 말 늦은 유아와 일반 유아 주양육자 집단 간 6 가지 직접발화 하위유형에 따른 빈도수의 차이를 살펴보기 위해 가정 내 일상생활 상황을 녹음하여 연구실험을 진행하였다.

유아와 상호작용하면서 산출된 6가지 직접발화 하위유형을 분 석한 결과, 6 가지 발화 유형 중 반응하기, 질문하기, 설명 및 명명하 기, 요구하기, 시도하기 유형에서 집단 간 차이가 통계적으로 유의 하였다. 즉, 말 늦은 유아 주양육자가 일반 유아 주양육자보다 질문 하기, 요구하기 유형에서 유의하게 높게 산출하여 유아와 상호작용 한 반면, 반응하기, 설명 및 명명하기, 시도하기 유형에서는 일반 유 아 주양육자보다 통계적으로 유의하게 낮게 산출하여 유아와 상호 작용하였다. 따라서 일반 유아 주양육자는 유아의 의사소통 표현 에 대해 즉각적인 반응과 상호작용 시도를 보다 많이 해주고, 사물 및 사건에 대한 설명과 이름대기를 통해 상호작용한 반면, 말 늦은 유아주양육자는 유아의 의사소통에 반응하기보다 질문하는 비율 이 높으며, 사물 및 행동을 요구하거나 언어를 산출하도록 요구하 는 비율이 높게 나타났다. 이는 주양육자의 언어적 입력양이 어휘 발달과 정적 상관관계가 있음을 발견하고 질적으로는 유아의 표현 에 대한 언어적 반응성이 언어능력을 예측해준다고 밝힌 선행연구 (Hart \& Risley, 1995; Snow, 1983)를 지지하며, 단순히 언어발달 속 도가 느린 유아와 일반 유아 집단 주양육자 간 상호작용 특성에서 유의한 차이가 나타났다고 보고한 선행연구(Feeley, Gottlieb, \& Zelkowitz, 2005; Girolametto, Weitzman, Wiigs, \& Pearce, 1999; Girolametto \& Weizman, 2002; Warren \& Brady, 2007)를 뒷받침 하였다.

선행연구에서 유아의 언어발달을 증진시켜주는 주양육자의 의 사소통 특성에는 반응하기, 설명하기, 유아의 말을 모방 및 확장하 기, 질문하기 유형으로 나타난다는 점에서(Chang \& Sung, 2011; Girolametto et al., 1999; Girolametto \& Weizman, 2002; Vigil et al., 2005) 본 연구는 일반 유아의 주양육자가 유아에게 반응하기, 설명 및 명명하기, 시도하기 유형이 유의하게 높게 나타나 선행연구 결과와 일치한 반면, 말 늦은 유아의 주양육자가 유아와 상호작용 할 때 질문하기 유형이 보다 높게 산출되어 선행연구결과(White- 
hurst et al., 1988)와 일치하지 않는다. 이는 본 연구에서는 구조화 된 상황에서 나타난 발화 유형이 아닌 일주일 동안 가정 내에서 산 출한 주양육자의 언어적 발화 유형을 분석한 것으로 선행연구보다 확장되고 포괄된 상황에서 살펴본 결과라고 할 수 있다. 또 다른 측 면에서 반응하기와 질문하기 유형으로 나누어 볼 때, 말 늦은 유아 주양육자가 언어적 상호작용에서 주도권을 가지고 있다고 볼 수 있 으며 즉, 유아가 표현하는 것에 반응해주기보다 주양육자가 질문을 보다 많이 제공하여 유아의 언어산출을 유도한 것으로 보인다. 따라 서 주양육자가 먼저 질문하기보다 유아가 상호작용하고자 하는 대 화 주제나 표현을 존중하면서 이를 모방하거나 확장시켜나가면서 반응해주는 것이 유아의 언어능력을 촉진시킨다고 해석할 수 있다.

본 연구에서 표현어휘 및 표현언어가 정상발달 범주에 있는 일반 유아 주양육자가 주로 유아의 언어에 즉각적인 반응과 의사소통을 시도하고, 사물에 대한 이름대기 또는 설명하기를 통해 상호작용 한 것으로 나타난 것은 선행연구(Vigil et al., 2005)에서 일반 유아 주양육자가 상호작용 시 유아의 언어를 모방하거나 확장해주면서 반응해주는 비율이 높다고 밝혔으며 사물에 대한 설명하기와같은 일부 의사소통 행동 유형에서 일반 유아주양육자와 유의한 차이가 나타났다고 밝힌 연구결과와 흐름을 같이한다. 또한 유아의 언어 및 행동을 인정 및 칭찬하기, 즉각적인 반응, 반복, 확장, 명료화 해주기 와 같은 언어적 반응성이 높을수록 유아의 언어발달에 촉진적 역 할을 할 수 있다고 주장한 연구결과(Moerk, 1983)를 뒷받침하였다. 즉, 선행연구에서 언급한 것과 마찬가지로 본 연구는 말 늦은 유아 의 주양육자와 일반 유아 주양육자 간 언어적 입력형태가 질적으로 차이가 있다는 것을 의미한다. 하지만 언어발달이 늦은 아동의 경 우 비교집단보다 표현하는 언어수가 상대적으로 적기 때문에 말 늦 은 아동 집단의 주양육자가 아동에게 직접적인 언어적 반응 및 질 문 등이 현저히 낮을 수 있다는 점을 고려하여 말 늦은 아동의 언어 능력을 확장시켜줄수 있는 요인을 다각적으로 살펴볼 필요가 있다.

한편, 상호작용 시 나타난 주양육자의 의사소통 유형에서 '혼잣 말하기'는 두 집단 모두 가장 낮은 비율로 나타났으며 집단 간 유의 한 차이가 나타나지 않았다. 본 연구에서 혼잣말하기 유형은 주양 육자가 다른 누군가를 흉내 내거나 유아에게 간접적으로 말을 전 달하는 표현으로 본 연구는 앞서 언급한 대로 구조화된 상황이 아 닌 가정 내 일상생활 상황으로 인해 인형이나 어떤 장난감을 통해 상호작용하기보다 주로 식사, 용변, 목욕, 수면과 같은 육아활동이 이루어졌으므로 주양육자가 제 3 자의 입장에서 유아에게 간접적 으로 언어를 표현한 경우가 낮았던 것으로 볼 수 있다. 즉, 선행연구 에서는 주로 장난감을 사용하여 구조화된 상황에서 나타난 주양 육자 발화를 본 것으로 일상생활에서 나타난 실제 주양육자 발화
유형과 다를 수 있다는 점을 감안하여, 임상에서 주양육자 발화를 평가할 때 단순히 장난감을 통한 상황보다 육아 활동에서 나타날 수 있는 발화를 유도하기 위해 육아 상황을 재현할 수 있도록 고려 해볼 필요성이 있다.

본 연구는 일상생활에서 나타난 주양육자의 직접발화 하위유형 을 분석한 것으로 말 늦은 유아 집단과 또래 일반 유아 집단 주양육 자 간 의사소통의 특성에서 유의미한 차이가 있었던 것을 확인함 으로써 유아와 대화를 할 때 유아의 언어 및 행동에 대해 언어적 의 미를 부여해주고, 유아가 알아듣기 쉽도록 간단하고 짧은 문장을 사용하여 반복적으로 반응해줄 필요가 있다.

결론적으로, 본 연구에서는 말 늦은 유아 및 또래 일반 유아의 주 양육자를 대상으로 직접발화 및 간접발화 빈도수에 따른 차이가 유의하게 나타났으며, 특히 말 늦은 유아 집단 주양육자 보다 일반 유아 집단 주양육자가 직접발화 빈도수를 유의하게 높게 산출한 것을 확인하였다. 또한 두 집단 간 주양육자의 발화특성에서 일반 유아 집단의 주양육자는 유아와 상호작용 시 반응하기, 설명 및 명 명하기, 시도하기 유형이 높게 나타난 반면 말 늦은 유아 주양육자 집단은 질문하기, 요구하기 유형이 유의하게 높게 나타난 것을 확인 하여 집단에 따라서 주양육자의 발화특성의 차이가 나타날 수 있 음을 발견하였다. 요약하자면, 주양육자와 유아 간 직접적으로 이 루어지는 언어적 상호작용이 주요한 요인이 될 수 있으며, 어떠한 언어적 형태로 상호작용을 해야 하는지를 확인한 점에서 본 연구 는 임상적 의의가 있다.

또한 임상에서는 실제로 구조화된 상황을 통해서 짧은 시간 동 안 유아의 발화분석을 실시하기도 하지만 주양육자의 상호작용 방 식 및 태도를 분석하기 위해 발화표본 수집을 실시하기도 한다. 하 지만 약 30 분간 유아와 상호작용하는 주양육자의 의사소통 형태 를 일반화하여 평가하기에는 한계가 있다. 따라서 보다 정확하게 평가하기 위해서 추후연구에서는 본 연구에서 실시한 실제 가정 내 일상생활에서 나타난 주양육자의 발화와 구조화된 상황에서 나타난 주양육자의 발화에 대한 다각적 비교 연구를 통해 어떤 조 건에서 발화가 일치하는지 살펴본다면 임상에서 유용한 지표로 사용될 수 있을 것이다. 또한 본 연구에서 주양육자의 직접발화와 간접발화는 일주일 동안 나타난 전체발화를 살펴본 반면, 주양육 자의 직접발화 하위유형은 일주일 중에 발화수가 가장 높았던 하 루를 분석한 것으로 일반화시키는 것에 한계가 있다. 따라서 후속 연구에서는 직접발화 하위유형 또한 일주일 동안 나타난 주양육자 전체발화를 바탕으로 분석할 필요가 있을 것으로 보인다. 또한 단 순히 녹음상황에서 나타난 발화를 분석한 점에서 큰 한계가 있으 며, 제 3 의 발화상대자가 유아와 친숙한 정도에 따라 간접발화의 양 
Jiyeon Lee, et al. • Direct and Overheard Speech of Primary Caregiver of LT and TD Infants

에 영향을 줄 수 있으므로 이를 고려하여 후속연구에서는 녹화상 황을 통해 보다 정확한 분석을 할 필요가 있을 것으로 보인다.

\section{REFERENCES}

Bates, E., \& Snyder, L. (1987). The cognitive hypothesis in language development. In I. C. Uzgiris \& J. M. Hunt (Eds.), Infant performance and experience: new findings with the ordinal scales (pp. 168-204). Urbana, IL: University of Illinois Press.

Bates, E., Dale, P. S., \& Thal, D. (1995). Individual differences and their implications for theories of language development. In P. Fletcher \& B. MacWhinney (Eds.), The handbook of child language (pp. 96-151). Oxford: Blackwell Publishing.

Bates, E., Marchman, V., Thal, D., Fenson, L., Dale, P., Reznick, J. S., ... \& Hartung, J. (1994). Developmental and stylistic variation in the composition of early vocabulary. Journal of Child Language, 21, 85-123.

Baumwell, L., Tamis-LeMonda, C. S., \& Bornstein, M. H. (1997). Maternal verbal sensitivity and child language comprehension. Infant Behavior and Development, 20, 247-258.

Billeaud, F. P. (2003). Communication disorders in infants and toddlers: assessment and intervention. St. Louis, MO: Butterworth Heinemann.

Bondrova, E., \& Leong, D. J. (1996). Tools of the mind: the Vygotskian approach to early childhood education. Englewood Cliffs, NJ: Merrill/Prentice Hall.

Bornstein, M. H., \& Tamis-LeMonda, C. S. (1990). Activities and interactions of mothers and their firstborn infants in the first six months of life: covariation, stability, continuity, correspondence, and prediction. Child Development, 61, 1206-1217.

Bornstein, M. H., \& Tamis-LeMonda, C. S. (1989). Maternal responsiveness and cognitive development in children. New Directions for Child and Adolescent Development, (43), 49-61.

Cazden, C. B. (1981). Social context of learning to read. In J. T. Guthrie (Ed.), Comprehension and teaching: research reviews (pp. 118-139). Newark, Delaware: International Reading Association.

Chang, Y. K., \& Sung, J. H. (2011). The relative contribution of infants, mothers, and family socioeconomic characteristics on expressive vocabulary acquisition of 24-month-old infants. The Korean Journal of Developmental Psychology, 24, 137-154.

Chang, Y. K., Lee, K. Y., Kwak, K. J., \& Sung, H. R. (2003). Relations of maternal linguistic inputs to lexical development of Korean infants. The Korean Journal of Developmental Psychology, 16, 227-241.
Durkin, D. (1961). Children who learned to read at home. The Elementary School Journal, 62, 15-18.

Feeley, N., Gottlieb, L., \& Zelkowitz, P. (2005). Infant, mother, and contextual predictors of mother-very low birth weight infant interaction at 9 months of age. Journal of Developmental \& Behavioral Pediatrics, 26, 24-33.

Feitelson, D., Kita, B., \& Goldstein, Z. (1986). Effects of listening to series stories on first graders' comprehension and use of language. Research in the Teaching of English, 20, 339-356.

Fernald, A., \& Marchman, V. A. (2012). Individual differences in lexical processing at 18 months predict vocabulary growth in typically developing and late-talking toddlers. Child development, 83, 203-222.

Fitzgerald, J. (1993). Literacy and students who are learning English as a second language. The Reading Teacher, 46, 638-647.

Gershkoff-Stowe, L. (2002). Object naming, vocabulary growth, and the development of word retrieval abilities. Journal of Memory and Language, 46, 665-687.

Girolametto, L., \& Weitzman, E. (2002). Responsiveness of child care providers in interactions with toddlers and preschoolers. Language, Speech, and Hearing Services in Schools, 33, 268-281.

Girolametto, L., Weitzman, E., Wiigs, M., \& Pearce, P. S. (1999). The relationship between maternal language measures and language development in toddlers with expressive vocabulary delays. American Journal of SpeechLanguage Pathology, 8, 364-374.

Ha, S. (2011). Parent-implemented early intervention for young children with cleft palate. Korean Journal of Communication Disorders, 16, 460-477.

Hart, B., \& Risley, T. R. (1995). Meaningful differences in the everyday experience of young American children. Baltimore, MD: Paul H. Brookes Publishing.

Heath, S. B. (1983). Ways with words: language, life and work in communities and classrooms. Cambridge: Cambridge University Press.

Hoff, E. (2003). The specificity of environmental influence: socioeconomic status affects early vocabulary development via maternal speech. Child Development, 74, 1368-1378.

Hong, G. H., \& Kim, Y. T. (2005). A longitudinal study of the acquisition of communicative intentions. Korean Journal of Communication Disorders, 6, 17-39.

Hurtado, N., Marchman, V. A., \& Fernald, A. (2008). Does input influence uptake? Links between maternal talk, processing speed and vocabulary size in Spanish-learning children. Developmental Science, 11, F31-F39.

Huttenlocher, J., Haight, W., Bryk, A., Seltzer, M., \& Lyons, T. (1991). Early 
vocabulary growth: relation to language input and gender. Developmental Psychology, 27, 236-248.

Jang, H. S., Seo, S. J., \& Ha, J. Y. (2011). Developmental assessment for the early intervention program planning. Seoul: Hakjisa.

Jones, C. P., \& Adamson, L. B. (1987). Language use in mother-child and mother-child-sibling interactions. Child Development, 58, 356-366.

Kim, Y. S., \& Kwak, K. J. (2010). The relationship between maternal verbal responsiveness, infant's social communication ability during infancy and language ability in early childhood. The Korean Journal of the Human Development, 17, 191-207.

Kim, Y. T. (2002). Language disorders in children. Seoul: Hakjisa.

Kim, Y. T., Kim, K. H., Yoon, H. R., \& Kim, H. S. (2003). Sequenced Language Scale for Infants (SELSI). Seoul: Special Education Publishing.

Lee, H. J., \& Kim, Y. T. (1999). Measures of utterance length of normal and language-delayed children. Korean Journal of Communication Disorders, 4, $1-14$.

Lee, J. A., Pyun, D. W., \& Kwak, S. C. (2011). Study of the selection of basic learning vocabulary for children with developmental disabilities: focus on children with kindergarten and elementary school. Korean Journal of Special Education, 46, 29-50.

Lee, J. Y., Lee, K. Y., \& Chang, Y. K. (2004). The effect of maternal verbal interaction style on infants' early vocabulary development during picture book reading. The Korean Journal of Developmental Psychology, 17, 131146.

Lee, S. B., \& Lee, H. R. (2007). Definitional category analysis of ambiguous words in Korean children with specific language impairment. Journal of Speech \& Hearing Disorders, 16, 1-18.

Leonard, L. B. (1998). Children with specific language impairment. Cambridge, MA: MIT Press.

Markus, J., Mundy, P., Morales, M., Delgado, C. E., \& Yale, M. (2000). Individual differences in infant skills as predictors of child-caregiver joint attention and language. Social Development, 9, 302-315.

Meins, E., Fernyhough, C., Wainwright, R., Clark-Carter, D., Das Gupta, M., Fradley, E., \& Tuckey, M. (2003). Pathways to understanding mind: construct validity and predictive validity of maternal mind-mindedness. Child Development, 74, 1194-1211.

Miller, D. (1991). A logic programming language with lambda-abstraction, function variables, and simple unification. Journal of Logic and Computation, 1, 497-536.

Moerk, E. L. (1983). The mother of Eve-as a first language teacher. Norwood,
NJ: Ablex Publishing.

Morrow, L. M. (1983). Home and school correlates of early interest in literature. Journal of Educational Research, 76, 221-230.

Ninio, A. (1980). Picture-book reading in mother-infant dyads belonging to two subgroups in Israel. Child Development, 51, 587-590.

Pae, S., \& Kwak, K. C. (2011). Korean MacArthur-Bates Communicative Development Inventories (K M-B CDI): user's guide and technical manual. Seoul: Mindpress.

Park, W., \& Yim, D. (2015). The effectiveness of parental education via smartphone application on number of utterances and initiation ratio. Communication Sciences \& Disorders, 20, 500-509.

Peterson, C. (1992). Explanatory style and health. In G. M. Buchaman \& M. E. P. Seligman (Eds.), Explanatory style (pp. 233-246). Mahwah, NJ: Lawrence Erlbaum Associates.

Reese, E., Haden, C. A., \& Fivush, R. (1993). Mother-child conversations about the past: relationships of style and memory over time. Cognitive Development, 8, 403-430.

Rescorla, L. (1989). The language development survey: a screening tool for delayed language in toddlers. Journal of Speech and Hearing Disorders, 54, 587-599.

Rowe, M. L., \& Goldin-Meadow, S. (2009). Differences in early gesture explain SES disparities in child vocabulary size at school entry. Science, 323, 951-953.

Shin, M., Kwak, K., \& Bornstein, M. H. (2007). Maternal verbal responsiveness relates to vocabulary development in Korean children at 13 and 20 months. Paper presented at the 2007 Biennial Meeting SRCD, Boston, MA.

Snow, C. (1983). Literacy and language: relationships during the preschool years. Harvard Educational Review, 53, 165-189.

Snow, C. E. (1972). Mothers' speech to children learning language. Child Development, $43,549-565$.

Snow, C. E. (1977). The development of conversation between mothers and babies. Journal of Child Language, 4, 1-22.

Thai, D., \& Tobias, S. (1994). Relationships between language and gesture in normally developing and late-talking toddlers. Journal of Speech, Language, and Hearing Research, 37, 157-170.

Ukoumunne, O. C., Wake, M., Carlin, J., Bavin, E. L., Lum, J., Skeat, J., ... \& Reilly, S. (2012). Profiles of language development in pre-school children: a longitudinal latent class analysis of data from the Early Language in Victoria Study. Child: Care, Health and Development, 38, 341-349.

Vigil, D. C., Hodges, J., \& Klee, T. (2005). Quantity and quality of parental 
language input to late-talking toddlers during play. Child Language Teaching and Therapy, 21, 107-122.

Warren, S. F., \& Brady, N. C. (2007). The role of maternal responsivity in the development of children with intellectual disabilities. Mental Retardation and Developmental Disabilities Research Reviews, 13, 330-338.

Weisleder, A., \& Fernald, A. (2013). Talking to children matters early language experience strengthens processing and builds vocabulary. Psychological Science, 24, 2143-2152.

Weismer, S. E., Murray-Branch, J., \& Miller, J. F. (1994). A prospective longitudinal study of language development in late talkers. Journal of Speech, Language, and Hearing Research, 37, 852-867.

Wellen, C. J. (1985). Effects of older siblings on the language young children hear and produce. Journal of Speech and Hearing Disorders, 50, 84-99.

Wells, G. (1986). The meaning makers: children learning language and using language to learn. Portsmouth, NH: Heinemann Educational Books Inc.

Whitehurst, G. J., Falco, F. L., Lonigan, C. J., Fischel, J. E., DeBaryshe, B. D., Valdez-Menchaca, M. C., \& Caulfield, M. (1988). Accelerating language development through picture book reading. Developmental Psychology, 24, 552-559.

Woollett, A. (1986). The influence of older siblings on the language environment of young children. British Journal of Developmental Psychology, 4, 235-245.

Yang, Y., Yim, D., \& Bae, K. (2015). Predictors of word learning in children with specific language impairment. Communication Sciences \& Disorders, 20, 1-12.

Yim, D., Park, W., Cheon, S., Lee, Y., \& Lee, J. (2015). Interaction skills via spontaneous speech sample analysis: 2- to 5-year-old children with and without language impairment. Communication Sciences \& Disorders, 20, 364-373.

Zutell, J. (1980). Children's spelling strategies and their cognitive development. In E. H. Henderson \& J. W. Beers (Eds.), Developmental and cognitive aspects of learning to spell: a reflection of word knowledge (pp. 52-73). Newark, Delaware: International Reading Association. 


\section{국문초록}

\section{말 늦은 유아(late talker)와 일반 유아 주 양육자의 직접발화 및 간접발화 비교 이지연 · 임동선 \\ 이화여자대학교 대학원 언어병리학과}

배경 및 목적: 유아기의 아동들은 언어능력수준에 많은 가변성을 보이나 주양육자와 유아 간 성공적인 의사소통 경험이 축적될수록 아동의 언어발달에 긍정적인 영향을 준다. 따라서 주양육자가 유아에게 풍부한 언어자극을 제공하는 입력량에 따라 말 늦은 유아집단 간 차이를 알아보고자 한다. 방법: 본 연구에 참여한 유아는 18-36개월의 유아와 주양육자 16 쌍, 그리고 이들과 생활연령이 일치하는 일반 유아와 주양육자 16 쌍이다. 가정 내 일상생활 상황에서 나타나는 유아에 대한 주양육자의 직접발화 및 간접발화를 분석하기 위 해 각 가정에 스마트폰과 스마트폰 암밴드를 제공하여 일주일간 일상생활을 녹음하였다. 결과: 말 늦은 유아 주양육자 집단에서 보다 일반 유아 주양육자 집단에서 직접발화 빈도수가 유의하게 높게 산출하였다. 주양육자의 직접발화 6 가지 하위유형 중 질문하기, 시도하 기, 설명 및 명명하기, 요구하기 유형에서 집단 간 차이가 통계적으로 유의하였다. 즉, 말 늦은 유아 주양육자가 일반 유아 주양육자 보다 질문하기, 요구하기 유형에서 유의하게 높게 산출한 반면, 반응하기, 설명 및 명명하기, 시도하기 유형에서는 일반 유아주양육자보다 통 계적으로 유의하게 낮게 나타났다. 논의 및 결론: 주양육자와 유아 간 직접적으로 이루어지는 언어적 상호작용이 주요한 요인이 될 수 있으며, 어떠한 언어적 형태로 상호작용을 해야 하는지를 확인한 점에서 본 연구는 임상적 의의가 있다.

핵심어: 말 늦은 유아, 유아-주양육자 상호작용, 주양육자 직접발화, 주양육자 간접발화

\section{참고문헌}

김연수, 곽금주(2010). 영아기 어머니의 언어적 반응성 및 영아의 비언어적 의사소통과 아동 초기 언어능력 간의 관계. 한국인간발달학회, 17, 191-207. 김영태(2002). 아동 언어 장애의 진단 및 치료. 서울: 학지사.

김영태, 김경희, 윤혜련, 김화수(2003). 영유아 언어발달 검사(SELSI). 서울: 도서출판 특수교육.

배소영, 곽금주(2011). 맥아더-베이츠 의사소통발달평가 전문가 지침서. 서울: 마인드프레스.

박원정, 임동선(2015). 발화분석 어플리케이션을 활용한 상호작용 증진 부모교육이 언어발달지연 아동과 부모의 발화 및 대화차례 개시에 미치는 영

향. 언어청각장애연구, 20, 500-509.

양윤희, 임동선, 배경란(2015). 학령기 단순언어장애 아동의 어휘학습 예측요인: 의미점화 및 간섭 효과. 언어청각임상학회, 20, 1-12.

이승복, 이희란(2007). 단순언어장애아동의 단어정의하기-정의유형 분석을 중심으로. 언어치료연구, 16, 1-18.

이지연, 이근영, 장유경(2004). 어머니의 책 읽기 상호작용 유형이 영아의 초기 어휘발달에 미치는 영향. 한국심리학회지: 발달, 17, 131-146.

이진아, 편도원, 곽승철(2011). 발달장애아동의 기초 학습어휘 선정에 관한 연구. 특수교육학연구, 46, 29-50.

이희정, 김영태(1999). 자발화 표본 분석의 정량화를 통한 언어발달지체의 판별 연구: 발화길이를 중심으로. 언어청각장애연구, 4, 1-14.

임동선, 박원정, 천성혜, 이여진, 이지연(2015). 자발화 분석을 통한 만 2-5세 아동의 상호작용 기술 특성 및 언어발달지체 아동 비교 연구. 언어청각장

애연구, 20,364-373.

장유경, 성지현(2011). 영아, 어머니, 가정의 사회경제적 특성이 24개월 영아의 표현어휘 습득에 미치는 상대적 영향. 한국심리학회지: 발달, 24, 137-

154.

장유경, 이근영, 곽금주, 성현란(2003). 어머니의 언어적 입력이 영아의 초기 어휘발달에 미치는 영향 한국심리학회지: 발달, 16, 227-241.

장혜성, 서소정, 하지영(2011). 영아선별 교육진단검사 전문가지침서: 0-36개월. 서울: 학지사.

하승희(2011). 구개열 영유아를 위한 부모 중심 조기언어중재가 말-언어발달에 미치는 효과. 언어청각장애연구, 16, 460-477.

홍경훈, 김영태(2005). 종단연구를 통한 ‘말늦은아동 (late-talker)’의 표현어휘발달 예측요인 분석. 언어청각장애연구, 10, 1-24. 